\title{
Amen to daat: on the foundations of Jewish epistemology
}

\author{
Samuel Lebens \\ Department of Philosophy, University of Haifa, 199 Abba Khoushy Avenue, Haifa 3498838, Israel \\ Corresponding author: Samuel Lebens, email: slebens@univ.haifa.ac.il
}

(Received 4 August 2021; revised 27 October 2021; accepted 29 October 2021)

\begin{abstract}
I argue that the Hebrew Bible adopts a non-doxastic account of propositional faith. In coming to this conclusion, we shall discover that Biblical Hebrew has no word for belief. What ramifications might this have had for biblical and Jewish epistemology? I begin to trace the sort of epistemic norms that might emerge from an epistemology that approaches knowledge by thinking about faith, rather than belief.
\end{abstract}

Keywords: Emunah; faith; non-propositional knowledge; Saadya Gaon; the Malbim

\section{Introduction}

What does it mean, for some proposition $p$, to have faith that $p$ ? In the first part of this article, I argue that the Hebrew Bible has a non-doxastic conception of propositional faith. This means that, according to the Hebrew Bible, one can have faith that $p$ without believing that $p$. In the process of sketching this biblical account of propositional faith, we come to the surprising conclusion that the Hebrew Bible recognizes the notions of faith and knowledge but has no word for belief.

The second part of this article explores the consequences that the existence of this strange lacuna has had for Jewish epistemology. Western epistemology is centrally interested in the road from belief to knowledge. Jewish epistemology, by contrast, is centrally interested in the road from faith to knowledge. This Jewish perspective on epistemology promises, I shall argue, to give rise to various insights worthy of further exploration. Accordingly, this article will concern itself, not with the ethical norms that emerge from the study of faith, but with the epistemic norms that we might discover. Indeed, I shall suggest that a faith-based approach will force us to reconsider what constitutes the summum bonum of epistemology.

\section{Searching the Hebrew Bible for propositional faith}

Philosophers discussing the nature of faith are quick to point out a key distinction between 'propositional faith' and 'non-propositional faith'. The first is faith that some proposition is true. The second, though it may require faith that certain propositions are true, doesn't take a proposition as its immediate object. Instead, we talk about faith

(c) The Author(s), 2021. Published by Cambridge University Press. This is an Open Access article, distributed under the terms of the Creative Commons Attribution licence (http://creativecommons.org/licenses/by/4.0/), which permits unrestricted re-use, distribution and reproduction, provided the original article is properly cited. 
in a person, or faith in a process, or faith in some ideal. For shorthand, we can talk about faith-in versus faith-that.

For some time, there was a scholarly consensus that the Hebrew Bible only explicitly recognized faith-in and seems to have had no place for faith-that. ${ }^{1}$ Indeed, the word emunah (אמונה), the Hebrew Bible's word for what we would call faith, generally takes nonpropositional objects; and it doesn't generally carry a that-clause. ${ }^{2}$ Indeed, the Bible tends to talk about emunah be'-x (i.e. faith in $x$ ) rather than emunah sheh-p (i.e. faith that $p$ is true).

Abraham was praised for having faith in God, not for having faith that certain propositions are true (Genesis 15:6). Moses and Aaron were criticized by God for not having demonstrated faith in Him (Numbers 20:12). They were not criticized for failing to demonstrate faith that certain propositions are true.

This observation can lead thinkers astray. Martin Buber, for example, would have us believe that propositional emunah didn't exist in the Jewish imagination at all until the medieval Rabbis began to turn to systematic philosophy (Buber (1951), 34). But, as Moshe Halbertal has pointed out, this is unlikely given that emunah in $x$, at the very least, presupposes propositional emunah. Could Abraham have had emunah in God if he didn't also, at least, have emunah that God exists, and that God is good (Halbertal (2005), 13-14)? $?^{3}$ Moreover, I would add that there are biblical verses (even if they're few and far between) in which the word emunah does takes a that-clause. God gives Moses a sign to show the Israelites: a staff that becomes a snake upon being cast to the floor, which reverts to being a stick when grasped by the tail. God gave this sign to Moses so that 'they [i.e. the Israelites] may believe that [ya'aminu ki] the LORD, the God of their fathers, the God of Abraham, the God of Isaac, and the God of Jacob, appeared to you' (Exodus 4:5).

I couldn't find many more examples in which emunah clearly takes a proposition as its object. ${ }^{4}$ Propositional emunah clearly doesn't take the limelight in the Hebrew Bible. It plays second fiddle to the much more central notion of emunah in God, which isn't straightforwardly propositional, and therefore doesn't take a that-clause. Fine. But that doesn't mean that the Hebrew Bible had no notion of propositional emunah. It evidently did. The question then becomes, what is it, and how does it differ (if at all) from what we English-speakers might call belief (as, indeed, it's commonly translated, as we saw even in my own translation of Exodus 4:5 above $\left.{ }^{5}\right)$ ?

To this day, the Hebrew language struggles to draw the distinction that we quite routinely draw in English between faith-that and belief-that. So, the question becomes, when emunah actually does function as a propositional attitude, in the Hebrew Bible, is it more like propositional faith, or is it more like belief? One route that promises to be particularly revelatory, in response to this question, is to investigate the word amen, which shares its root with emunah.

Jews, Christians, and Muslims alike use the word 'amen' to give public assent to something that's just been said. 'Amen' doesn't take a that-clause. Nevertheless, it is only said in response to the utterance of some statement or other. In other words, utterance of 'amen' seems to make anaphoric reference to a proposition or statement recently uttered, and it allows a second speaker to assert that which was just said. Is that all there is to it? How does the word appear in the Hebrew Bible?

The word appears in four chapters of the Book of Psalms (51, 72, 99, and 106). There it appears in its familiar liturgical context; much as it is still used in Abrahamic places of worship to this day. In the rest of the Hebrew Bible, it appears in only seven chapters. Following a suggestion of Rabbi Yehuda bar Simon (Midrash Devarim Rabba 7:1), we can divide all of these appearances of the word into three categories. 
Use 1: Sometimes the word is used to take an oath. In this manifestation of the word, a priest, or some other official, will read the words of the oath that a member of the public is obligated to swear, and, instead of repeating the oath word for word, the oath-taker merely needs to say 'amen'. The emphasis here isn't that the words that have been uttered are true. Instead, the emphasis is that the person saying 'amen' becomes legally bound by them. This takes care of the function of the word as it appears in Numbers 5:22.

Use 2: Sometimes 'amen' is uttered as an act of acceptance ${ }^{6}$ - for example, when we accept upon ourselves the consequences of our covenant with God. In a ceremony that the Jewish people performed upon coming into the land of Israel, the Levites were instructed to proclaim, 'Cursed be anyone who makes a sculpted or molten image, an abomination to God, the work of the hand of a craftsman, and sets it up in secret' (Deuteronomy 27:15). In response to this proclamation, and many others like it, the assembled Israelites were instructed to say 'amen' (ibid.). According to Rabbi Yehuda Bar Simon, the point of saying 'amen' here isn't merely to express agreement with the content of the proclamation. Rather, the point is that the people are accepting upon themselves, as a consequence of their coming into a covenant with God, that there will be negative consequences upon transgression. They are accepting that risk upon themselves. This second function of 'amen' takes care of the appearance of the word in Jeremiah 11:5 and Nehemiah 5:13 (in addition to all of the instances in Deuteronomy 27).

Use 3: The third use of 'amen' expresses a hope: the hope that the proposition just uttered should turn out to be true. We see this use of the word at the opening of 1 Kings. When David announced from his deathbed that Solomon would be his successor, "Benaiah son of Jehoiada spoke up and said to the king, "Amen! And may the Lord, the God of my lord the king, so ordain"” (1 Kings 1:36). With various powerful challengers waiting in the wings, Benaiah had good reason to doubt that David's dying wishes would be respected. But he certainly wanted them to be. ${ }^{8}$

All the other uses of the word 'amen' in the Hebrew Bible take place in something like a liturgical setting (which we could call use 4), uttered in response to blessings, or in affirmation of words of praise (as in every instance in the book of Psalms, in Nehemiah 8:6, and in I Chronicles 16:36). ${ }^{9}$ How does use 4 work?

Somebody utters a prayer, and we say 'amen'. We express not merely our belief that what has been said is true (and perhaps not even a belief that it's true), so much as our heartfelt desire that it be true (use 3). In addition to that, operating on the (perhaps beliefless $)^{10}$ assumption that it's true, we accept upon ourselves the consequences of its truth, even if some of those consequences might be painful or risky (use 2). And in addition to that, we commit ourselves, like a person taking an oath, to live our lives on the (perhaps beliefless) assumption of its truth. We commit ourselves to shaping our behaviour in light of the content of what has been said (use 1). All of that we do, according to Rabbi Yehuda bar Simon, when we say 'amen' to a prayer (in other words, when saying 'amen' in a liturgical setting, we tend to be using the word in all three of its senses at once and thus use 4 is wholly parasitic on uses 1,2 , and 3). Consequently, saying 'amen' in the midst of a prayer service is, the Midrash tells us, particularly precious to God: Indeed, "nothing is greater before the Holy One, blessed be He, than the "amen" that an Israelite answers' (Deuteronomy Rabba 7:1). ${ }^{11}$

Rabbi Yehuda bar Simon's analysis of the uses of the word 'amen' in the Hebrew Bible is exhaustive ${ }^{12}$ and compelling.

Given the close etymological tie between amen and emunah, I would like to suggest that when emunah appears in the Hebrew Bible, as we know it sometimes does, as a 
propositional attitude, it is equivalent to the subject of that attitude saying, regarding the proposition in question, 'Amen to that!' In other words, when emunah appears as a propositional attitude towards $p$, the subject of that attitude is being said to have any one, or any combination, of the following: (1) a commitment to shape her behaviour against the operative assumption that $p$ is true; (2) a personal willingness to accept the risks that follow from the truth of $p$, and/or (3) the desire that $p$ is true. No single element of this list, and no combination of them, approaches what we English speakers tend to mean by belief.

To have propositional emunah that $p$ is equivalent to saying, 'Amen to $p$ !'

Accordingly, propositional emunah in the language of the Bible is closer to faith than it is to belief. Indeed, the picture that emerges finds a profound consonance with the various non-doxastic accounts of propositional-faith found in the contemporary literature on the topic. ${ }^{13}$ Belief isn't even a component part of the biblical conception of propositional-faith, although - presumably - to harbour the hope that $p$ is true, is generally to have some non-zero credence in the truth of $p$. Does that credence have to amount to belief? Not necessarily. ${ }^{14}$

The Hebrew Bible, it seems, would take the side of those philosophers today who argue that faith can be a propositional attitude, and that the attitude in question needn't include belief that the proposition is true. ${ }^{15}$ But the conclusion we've come to brings a surprising result in its wake. The Bible, we have discovered, has a word for propositional faith. It also has a word for knowledge - that word is daat. Admittedly, daat is not always used to refer to propositional knowledge - but often it is. Now it turns out that, since propositional emunah is a species of faith, and not a species of belief, the Hebrew Bible has no word for belief. Faith? Yes. Knowledge? Yes. Belief? No. ${ }^{16}$

But hold on a minute! Doesn't knowledge (at least so far as knowledge is propositional) entail belief? Well, maybe. Knowing that $p$ would certainly seem to demand some pretty high degree of confidence that $p$ is true. But it nevertheless remains the case that the Biblical Hebrew has a name for knowledge, and it doesn't have a name for belief. ${ }^{17}$ This isn't to say that the notion would have been totally alien to the Hebrew mind. The Bible describes people as saying things in their hearts (e.g. Psalms 14:1) and thinking thoughts (e.g. Isaiah 55:8). The notion of belief cannot have been far away from the cognitive reach of an ancient Israelite. But still, the notion wasn't deemed central enough to require a word of its own. What are we to make of that?

\section{Building a bridge from emunah to daat}

One way to characterize the central challenge of western epistemology, at least since Edmund Gettier's hugely influential intervention (Gettier, 1963), and probably ever since Plato, is to provide an account of what needs to be added to belief to give rise to knowledge. Not all beliefs count as knowledge. For one thing, beliefs can be false whereas knowledge can't. Moreover, we can't even claim that all true beliefs count as knowledge. Only if a true belief is sufficiently justified, or warranted, or in some other way beyond epistemic repute, can it count as knowledge. But what exactly is justification? What counts as evidence and when? How much of it suffices? What is warrant? Addressing these questions, the task of Western epistemology has been to build a bridge from belief to knowledge.

But, if the Hebrew Bible has no word for belief, it's unlikely that biblical epistemology, and Jewish epistemology in its wake, is going to be all that interested in building the bridge that has fascinated epistemology in the West. Instead, the central task is going to be one of moving from emunah (be it propositional, or more often than not, nonpropositional) all the way to daat; a bridge from faith to knowledge. 
Exploring the tight relationship between belief and knowledge has led Western epistemology to cast the one very much in the image of the other. One manifestation of this is the temptation, going back to Plato, to think of knowledge as a special type of belief - the gold-standard of belief. Another manifestation is the more recent tendency, by some post-Gettier philosophers, to think of knowledge as a primitive concept, and to define belief in terms of knowledge, such that belief becomes something like substandard knowledge (Williamson, 2000). But what happens when the temptation isn't to cast knowledge in the image of belief (or vice versa), but the temptation is to cast knowledge in the image of faith (or vice versa)?

In what follows, I will sketch three different, and influential, ways in which Jewish epistemology has sought to build its bridge between emunah and daat - faith and knowledge before drawing some general conclusions about what Jewish epistemology might have to contribute to the wider world.

\section{The bridge of Saadya Gaon}

The philosophical magnum opus of Saadya Gaon was called, in its original Arabic, Kitāb al-Amānāt wa l-i'tiqādāt. This translates directly into Hebrew, using the same Semitic roots for the two key terms, as Sefer al Emunot Va'Deot, or as its Hebrew translation was dubbed, simply, Emunot Va'Deot. In other words, the book was about matters of emunah and matters of daat: faith and knowledge. What did Saadya Gaon mean by 'amānā (or emunah), and what did he mean by 'itiqādāt (or daat)? And what was the difference between the two?

Alexander Altmann conducted a thorough survey of the two words, in the original Arabic version of Saadya's text. He came to the conclusion that emunah, quite unlike the biblical picture sketched above, is a species of belief. What's special about it seems to be twofold: (1) the content of emunah is believed on the basis of transmission from prophets to the people, and from one generation of the people to the next; ${ }^{18}$ (2) the content of emunah exclusively concerns matters of religious doctrine. Daat, by contrast, 'signifies an attitude of firm belief as a result of a process of speculation' (Altmann (1946), 19).

In actual fact, Saadya Gaon went to some lengths to argue that religious doctrines known by transmission through a reliable chain of testimony count, not merely as belief, but as knowledge. And thus, the bridge he wants to build isn't really a bridge from faith to knowledge so much as a bridge from one sort of knowledge (emunah) to another (daat); a bridge that leads us from knowledge by testimony, or transmission, or tradition, to knowing the same propositions in a more direct fashion - as the conclusion of a process of reasoning that begins with premises that are self-evident, either by the light of reason, or in light of our sense-data, and moves towards its conclusion only in watertight truthpreserving steps.

As Altmann rightly points out, 'The title of the book thus epitomizes the whole purpose which the author had in mind, namely to enable the reader to reach a stage where the propositions known by emunah come to be known by daat' (ibid., 20). Indeed, throughout the book, Saadya will typically list a number of things that he knows by emunah before introducing a process of reasoning that is supposed to transform that knowledge into daat.

As an illustrative example, take the first chapter of the first treatise. There, Saadya Gaon begins by saying that 'our Lord, exalted be He, made it known to us that all things were created and that He had created them out of nothing. Thus scripture says: In the beginning God created the heaven and the earth (Gen. 1:1)' (ibn Yusuf (1976), 40). Having set that as his starting place, he goes on to say, 'I next inquired into this matter to see whether it could be supported by reason as it had been verified by prophecy, and I found that it could be thus supported in many ways. Out of the sum of these I shall 
excerpt four proofs', and thus begins the presentation of those proofs (ibid., 41). This pattern is repeated throughout the book.

Saadya knows his conclusions before he proves them. He's not looking for new knowledge, rather, he's looking for a new sort of grasp of that which he already knows. He's looking to transform emunah into daat. In the introduction to his book, Saadya gives a wonderful example to illustrate his purpose. He asks us to imagine the situation of:

a person who out of a total of 1,000 drachmas weighs out 20 to each of five men, and $16 \frac{2}{3}$ to each of six, and $14 \frac{2}{7}$ to each of seven, and $12 \frac{1}{2}$ to each of eight, and $11 \frac{1}{9}$. to each of nine, who wishes to check with them quickly on how much money is left. So he tells them that the remainder amounts to 500 drachmas, supporting his statement by the weight of the money. Once, then, it has been weighed by them quickly and found to be 500 drachmas, they are compelled to credit his statement. Then they can take their time until they find out [that] it [is really so] by way of calculation, each one according to his understanding, and the effort he can put into it and the obstacles he might encounter. (ibn Yusuf (1976), 32-33)

To modernize the example, think of a reliable calculator. You type in the sum ' $17.859 \times(45$ $\div 9.6$ )' and it will tell you that it equals 83.7140625 . Given the reliability of the calculator, it would be absurd to say that you don't know the equation in question to be true. But even so, you know it differently when you've actually worked it out for yourself. This difference is a very good analogy for the gap between knowledge by emunah and knowledge by daat, in the epistemology of Saadya Gaon.

of the accounts that we shall examine in this article, Saadya's overall epistemology comes closest to the classical western tradition. I say this because Saadya's epistemic summum bonum is daat, which, as he construes it, would be recognized by any western epistemologist as bog-standard well-founded propositional knowledge. The other models that we'll encounter have a very different conception of what our epistemic end point should be. Even so, Saadya's interest isn't to transform propositional belief into propositional knowledge. His aim is to add a certain sort of depth to the grasp with which propositional knowledge is held.

\section{The bridge of Rabbi Meir Wisser (known as the Malbim)}

Our second model for the bridge between emunah and daat is well expressed in the commentary of the Malbim to the book of Hosea. In a well-known and beautiful passage, Hosea foresees a reconciliation between God and his wayward people. God speaks:

And I will betroth you to me forever: I will betroth you to me with righteousness and justice, and with goodness and mercy. And I will betroth you to me with emunah; and you will know [ve'yada'at] the Lord. (Hosea 2:21-22)

Surely a more straightforward way to write the first verse would have God betroth his people with 'righteousness, justice, goodness, and mercy' rather than with '<righteousness and justices, and <goodness and mercys'. Accordingly, the Malbim imagines that the betrothal is more like an exchange of gifts. The Jewish people will bring their 'righteousness and justice', and God will reciprocate by bringing His 'goodness and mercy'. I quote: 
And because you will bring as a dowry, two precious matters, which are righteousness and justice, the bridegroom will bring to them, correspondingly, also two precious presents, which are goodness and mercy. (ibid.)

The eschaton, with its heightened revelation of God's goodness and mercy, will be precipitated, in part, by the Jewish people observing the commandments that govern the relations between human beings; commandments which are underpinned by righteousness and justice. The next verse, according to the Malbim's reading, deals with those commandments that concern the relationship between human beings and God:

And corresponding to the commandments between a man and God, whose essence depends upon emunah, [and therefore depend upon a person] having faith in God, and in His Torah, and in His providence; regarding this, it says, 'I will betroth you to me in emunah.' And after you, the bride, bring this gift in your hand, which is emunah, he will bring for her, corresponding to it, a present from his side, that you will know the Lord; that signs and wonders will be revealed to her, and the divine presence will dwell among them until they know the Lord with clear knowledge like sense perception, that they will no longer require emunah, for emunah is directed towards matters over which we have no clear knowledge, and is only received [i.e. as a cultural inheritance], but they will have knowledge, to know the Lord, and this is greater than emunah. (ibid.) ${ }^{19}$

On a cursory reading, the Malbim's conception of emunah bears a striking similarity to the conception of Saadya Gaon. Saadya's conception has to do with doctrines that have been transmitted to us by tradition, and the Malbim also speaks about emunah as things that are known through reception, which is to say, via a cultural inheritance. But, on closer inspection, the Malbim's examples of emunah are not doctrinal. They are not even propositional. Rather, the Malbim is interested in a person's faith in God, and in God's Torah and in providence (even if these attitudes have been socially conditioned). This is faith-in rather than faith-that. This makes sense given that faith-in is more prominent in the Bible than is faith-that. But then, notice how the knowledge that Israel gains of God, in the eschaton, also isn't propositional. They come to know God with a directness that's equivalent to sense-perception. Amidst signs and wonders and sensory overload, what they come to know is more like phenomenal knowledge than propositional knowledge.

Why do I say that phenomenal knowledge isn't propositional? Frank Jackson (1982) put forward a thought experiment about the brilliant neuroscientist, Mary, who - despite growing up in a totally black and white environment - knows every true proposition that a complete neuroscience (and, indeed, a complete physics) could furnish her about the human experience of the colour blue. Given her environment, she can't know what the colour blue looks like. Jackson's point isn't about the relationship between phenomenal and propositional knowledge. All he's interested to prove is that knowing everything there is to know about physics isn't to know everything there is to know about the world. There are facts that are not physical facts. But we should ask, what sort of knowledge of the world does Mary gain, when she finally discovers what blue looks like?

As Eleonore Stump points out, what Mary learns upon seeing blue for the first time doesn't seem to be merely the truth of a new proposition. Admittedly, she does learn the truth of new propositions, such as the proposition that 'blue looks like this', but "the "this" here simply gestures toward what she [has come to know]: it does not reduce it to propositional form' (Stump (2012), 51). In other words, 'knowing a color is a 
candidate for a kind of knowledge that is not' propositional (ibid.); a kind of knowledge that seems to be more intimate and direct than propositional knowledge.

The epistemic summum bonum, as far as the Malbim is concerned, is daat, and daat isn't a form of propositional knowledge. The fiancée, in Hosea's vision, knows that God exists. She knows it in virtue of an emunah that comes to her through some sort of cultural transmission. But it's knowledge nonetheless. What she gains in the wake of God's gift of daat is not a new proposition. And, unlike Saadya's suggestion, it isn't even (primarily) a new grasp over an old proposition. Rather, what she gains is an item of non-propositional knowledge that somehow shines a new light on what she knew before - much like Mary's experience of blue shines a new light on all the many things she already knew about that colour - and much more important than any new light shone upon the things that she previously knew about God, she has also come to know God!

Despite this difference between the Malbim and Saadya Gaon, it's worth pausing to reflect some more upon the similarity. Both of them think of the epistemic end point daat - as growing not from a flower bed of discrete beliefs independently arrived at in consultation with the evidence. Rather, both of them think of daat as growing from a flower bed that is deeply implicated in a particular social context. On this view, the epistemic process is rooted in a person's particular communal setting. Emuna is, at least in part, a communal heritage.

Elsewhere, I have argued at length that the Rabbinic attitude to conversion, which seems much more concerned with a potential convert's attachment to the Jewish community than with her theological convictions, is explained by an underlying Rabbinic epistemology. According to that epistemology, religious knowledge isn't stable unless it's situated and sustained within the context of a community. Referring to the biblical story of Ruth and Naomi, I put the point as follows:

Had Ruth experienced an epiphany, Naomi might have been sceptical. One day she has a mystical vision driving her towards Judaism; perhaps the next day she'll have a different vision pushing her in a different direction. Instead, Ruth's primary commitment was to Naomi and to her people. In the long term, this made it more likely that if and when Ruth did embrace the theology of Judaism, she'd do so with a steadfast resilience. (Lebens (2021a), 385)

Though it isn't my intention to align Jewish epistemology with any of the theories that have been called 'communitarian epistemology', ${ }^{20}$ there is certainly a communitarian element here. If daat emerges from emunah and if emunah is a social phenomenon, then an epistemic agent cannot fully function without belonging to some community or other.

\section{The Bridge of the Baal Shem Tov}

The founder of Hassidism, Rabbi Yisrael ben Eliezer - known as the Baal Shem Tov, said this to his students: 'After all of the understandings that I understood on high regarding the roots of the Torah and the commandments, and after all of the enjoyment [I received] from my understanding, I place all that I understood to one side. I cling to my simple faith [my emunah peshutah]', before adding in Yiddish 'איך בין א נער און גלייב' (I am a youngster and a believer, which translates idiomatically to 'I have a childlike faith'). ${ }^{21}$

We see here the promotion of a childlike faith above theoretical knowledge. Indeed, some Rabbinic texts imagine Abraham discovering God as a young child - perhaps in anticipation of the veneration of childlike faith. ${ }^{22}$ Other Rabbinic texts present Abraham arriving at monotheism as an adult, ${ }^{23}$ landing upon prototype versions of the 
design and/or cosmological argument. ${ }^{24}$ I once heard my Rosh Yeshiva (that is to say, the head of my Rabbinical Seminary), Rabbi Aharon Lichtenstein, say that the challenge in our religious lives is to emulate both portraits of Abraham at once. The challenge is to have a relationship with God that captures both the naivety of a childlike faith and the sophistication of a theologian.

In the Hassidic imagination, it seems, childlike simple faith - emunah peshutah - has to function as the foundation. Moreover, many Hassidic masters insist that every Jew (perhaps by dint of their election) has this emunah already. I think that this exclusivism is an unfortunate feature of Hassidic thought that can easily be put to one side. When these writers talk about every Jew, the reader can (and I think should) simply substitute the word 'person' for 'Jew'.

With that disclaimer in place, witness the claim, recorded in Torat Avot (a compendium of Hassidic teachings from the dynasties of Lechovich, Kobrin, and Slonim), that:

a Jew needs to have faith that in the inner recesses of his soul, he is [already] a person of faith, and that [to the extent that he endures a crisis of faith] it is merely [a certain] coarseness that covers the light of his faith, and [now, because he knows that deep down he really has faith] the [partially] fallen shouldn't fall [further] in his spirit. $^{25}$

Similarly, the great Hassidic master Rav Tzadok Hakohen proclaimed: 'And in truth, each and every Jew has emunah that everything comes from the Lord, may He be blessed, and that He is the source of sustenance and that He is the provider. ${ }^{26}$ But of course, Rav Tzadok was aware that many people, both Jewish and non-Jewish, would deny possessing such faith. His response is that the power of free will, which God, may He be blessed, wanted to be in the world, spreads out to the root [of each person], and it is possible [for it] to damage [while it's there] even the root of emunah which is [otherwise] fixed in the heart. ${ }^{27}$

In a similar vein, the great popularizer of Hassidic thought, Rabbi Shalom Noach Berezovsky (known as the Netivos Shalom), explains as follows:

Anybody who sees the creation in its entirety, planned in all its splendour, and full of wonderous things, granted a small amount of wisdom and knowledge, will see eye to eye, through them, [to] the creator, may He be blessed, who fixed the sun and the moon and all the planets in their precise orbits, and the like. And on the contrary, how is it possible not to be a person of faith, God forbid? . . . Rather it is only the blemish in a person that creates barriers and covers, which cut up and obscure the light of emunah, and they are like walls that block out the rays of the sun. (Berezovsky (1982), 46)

There are elements of this picture that are reminiscent of Alvin Plantinga's reformed epistemology. Plantinga sought to rehabilitate John Calvin's notion of a sensus divinitatis; some sort of an inner awareness of God that God placed in our minds. But clearly, not everyone is aware of God, so something must be going wrong. Plantinga's response is to define the sensus divinitatis not as the awareness of God itself, but as:

a kind of faculty or a cognitive mechanism, ... . which in a wide variety of circumstances produces in us beliefs about God. These circumstances, we might say, trigger the disposition to form the beliefs in question; they form the occasion on which those beliefs arise. Under these circumstances, we develop or form theistic beliefs. (Plantinga (2000), 172) 
Some people don't come to believe in God, but perhaps that's only because they don't find themselves in the right sort of situation; the sort of situation that triggers the sensus divinitatis. A more likely or more common explanation would be that something has somehow 'compromised, weakened, reduced, smothered, overlaid, or impeded' their God-given cognitive faculties, and that something, Plantinga would argue, is $\sin$ (ibid., 184).

Plantinga's conception of the sensus divinitatis is strikingly reminiscent of the 'light of emunah' in the words of the Netivos Shalom. It is more like a faculty than a belief or an awareness. And, when unimpeded, it leads to the formation of properly basic beliefs, that is to say, beliefs that are held not on the basis of some sort of inference. Plantinga likens this to the faculty of perception, which issues beliefs as an out-put (Plantinga (2000), 175). So too, the Netivos Shalom talks about seeing God somehow 'eye to eye.' Plantinga goes further and explains that if God actually exists, then the beliefs that the sensus divinitatis generates can constitute knowledge:

The purpose of the sensus divinitatis [if it was really placed in us by God our designer] is to enable us to have true beliefs about God; when it functions properly, it ordinarily does produce true beliefs about God. These beliefs therefore meet the conditions for warrant; if the beliefs produced are strong enough, then they constitute knowledge. (ibid., 179)

But careful attention to the words of the Netivos Shalom make it clear that beliefs aren't really the result of the unimpeded light of emunah. What one comes to know isn't that God created the world, or that God exists; instead, it's as if the light is shone upon God Himself. It is God Himself that you come to know.

This is reminiscent of Bertrand Russell's (1914) distinction between knowledge by description and knowledge by acquaintance. You can know that all sorts of propositions are true about some being called 'God' without being directly acquainted with God Himself. You can know, by description, that certain facts obtain without being acquainted with those facts. Acquaintance is not propositional. Even though a fact has the same sort of structure as a proposition (which is why propositions are able to represent facts), to be acquainted with a fact is not to assert that it obtains, or to know it via some representation, or proposition. It is for that fact to be present before you. Moreover, acquaintance with the constituents of facts can give you epistemic access to things that don't necessarily have any internal structure at all (like the soul of another, or even God (if such things exist and are within reach of the relation of acquaintance)).

It's this sort of acquaintance with God, rather than any particular propositional belief, which is held to be the ultimate result of unimpeded emunah. It will strike people as intolerably paternalistic to claim that all people, deep down, already believe that God exists (although, to be fair, intolerable paternalism doesn't entail falsehood). Thankfully, the claim of the Netivos Shalom, that all people have a faculty for coming to an unmediated knowledge of God, escapes this accusation.

As we saw with the Malbim, it is knowledge of a non-propositional sort that serves as the epistemic summum bonum for the Netivos Shalom. Mary's non-propositional knowledge regarding the colour blue was able to shine a new light on everything else she knew about the colour, and gave all of her knowledge a sort of qualitative boost. And much more importantly than that, she'll also have learnt what blue looks like! So too, it is a direct acquaintance with God that will shine a new light on everything we thought we already knew about Him, and much more importantly than that, it will bring us into epistemic contact with God Himself. ${ }^{28}$ 
When an epistemology is founded upon bridging the gap between faith and knowledge, it arrives at a different conception of what our ultimate epistemic aims should be. What do we gain when, in addition to knowing a fact, we become acquainted with the fact itself, and/or with some of its constituents? Does it result in an increased confidence, justification, or warrant? Or, do the terms of classical epistemology fail to describe what it is we've gained? Is it, perhaps, a knowledge that's deeper rather than a knowledge that's more certain? ${ }^{29}$

of course, it's not merely the fact that emunah doesn't have to be propositional that leads us to this distinctive epistemology. It's also the fact that daat itself - the biblical term for knowledge - also allows for non-propositional objects. Indeed, the very first instance of the word in the Hebrew Bible appears when Adam first knew his wife. The sort of knowledge that sits at the top of the epistemic hierarchy needn't be of a propositional form.

In fact, it is for this reason that the Baal Shem Tov wanted to put all of the things he had understood to one side. They were all just propositions. The thing that he really treasured was the unimpeded light inside him that shone directly, so to speak, upon the face of God. To the extent that we use the word daat to refer to mere propositional knowledge, the Hassidic tendency is to beware, since we can do so much better. To the extent that daat is propositional, Hassidic thinkers will sometimes prefer to reach for what they will call bina (understanding) or binat halev (understanding of the heart).

The Izbicer Rebbe, Rabbi Mordechai Yosef Leiner, comments on the extremely bizarre Rabbinic obligation to drink so much alcohol on the festival of Purim that one will no longer know (ad d'lo yadaa) the difference between 'cursed is Haman', the villain of the story, and 'blessed is Mordechai', one of its heroes (see Babylonian Talmud, tractate Megila, 7b). This is the Izbicer's very Hassidic explanation of that peculiar injunction:

And this is what [the Talmud means when it says] 'a person is obligated [to become intoxicated] until he doesn't know', which is to say, without daat and recognition, [but] only through the understanding which [resides] in the heart will he know that cursed is Haman and blessed is Mordechai. (Leiner (1995), 258)

The idea isn't to wash away our knowledge of the ethical facts of the Purim story. Instead, the idea is to raise to such an epistemic height in the midst of religiously inspired intoxication that one becomes directly acquainted with the ethical facts themselves, without the need for the interposition of any propositions.

\section{Conclusion}

My aim hasn't been to endorse any of the model bridges that I sketched in this article. They were, indeed, nothing more than sketches. Moreover, the three models present slightly conflicting pictures, so I couldn't consistently endorse them all. Instead, what I have sought to establish is this:

1. The most straightforward reading of propositional faith as it appears in the Hebrew Bible will probably be non-doxastic. To have faith that $p$, as far as the Hebrew Bible is concerned, is equivalent to saying, 'Amen to $p$ !'

2. Given this reading of propositional-emunah, it turns out that the Hebrew Bible has no word for belief.

3. Whereas classical epistemology has been fixated on bridging the gap between belief and knowledge, Jewish epistemology is more often interested in bridging the gap between faith and knowledge (or more precisely, between emunah and daat). 
I hope to have done enough to show that this different project, at the heart of Jewish epistemology, is worthy of further exploration. If pursued in greater depth, it promises to shed light on the various ways in which epistemic agency might be rooted in a person's social context (the flower bed of emunah). Moreover, it is likely to provide competing accounts of what our ultimate epistemic aims should be; inspiring us to question various assumptions, regarding epistemic norms, which have gone unchallenged for too long. ${ }^{30}$

\section{Notes}

1. See, for example, Kohler (1906); Heinemann (1950); Abrahams et al. (2007).

2. I know of only two exceptions in the Hebrew Bible (see note 4).

3. In correspondence, Daniel Howard-Snyder pushes back against this argument. A rhetorical question, he fairly points out, is no substitute for an argument. Moreover, why must Abraham's faith in God have been grounded in propositional-faith towards the propositions in question? Why wouldn't some other cognitive state, in relation to these propositions, suffice to ground his faith in God? To use Howard-Snyder's example:

why couldn't David put his faith in the LORD to deliver him from Saul where the cognitive requirement in view was some degree or other of confidence that the LORD would deliver him? Why would it have to be propositional faith, rather than propositional this or that for a variety of cognitive this or thats?

Sadly, I don't have space in this article to lay out a thorough argument to defend Halbertal's conclusion here. But I'll say this much: what we're looking for is a cognitive attitude towards a proposition that amounts to a non-zero confidence that it be true, in combination with various pro-attitudes (since, if Abraham didn't want the propositions in question to be true, or think them to be important, the attitude in question is unlikely to engender faith in God). Accordingly, propositional faith seems like a particularly good candidate, to say the least.

4. The only other example I could find in which the verbal form of emunah takes a that-clause, as it does in Exodus 4:5, is Job 9:16. But there are cases in which emunah is directed towards the content of people's speech, for example: Isaiah 53:1; Psalms 106:12; Psalms 106:24.

5. This translation was forced upon me, as it was forced upon other translators, in large part because English doesn't have a verbal form of the word for faith. To talk of someone 'having faith that p' is slightly more clunky than to talk of them simply 'believing that $p$ '. The fact that English doesn't have a verb for faith is perhaps the reason why the Encyclopaedia Judaica has an entry on 'Belief (Abrahams et al., 2007), but no entry on 'Faith', and (as we've just seen) explains why 'belief' appears more frequently in translations of the Hebrew Bible than perhaps it should.

6. As should become clear from what follows, I'm not here using the word 'acceptance' in its standard epistemological sense, as a propositional attitude that falls short of belief. I'm using it in a different sense entirely. William Alston was also keen to distinguish between the propositional attitude that falls short of belief, which he dubs acceptance, and the act of acceptance, but the sense of 'acceptance' I'm appealing to is, I think, altogether different from what Alston has in mind. For Alston, both the propositional attitude and the act of acceptance have a proposition as their object (Alston (1996), 8-9). My notion of acceptance is broader than that. What I have in mind by the act of acceptance here is best summed up in the beautiful words that Ruth says to Naomi in the first chapter of the book that bears her name. She says, 'Where you die, I will die, and there I will be buried. Thus and more may the LORD do to me if anything but death parts me from you' (Ruth 1:17). She seems to be saying, 'I know that bad things might happen to me on my journey with you. I know that it won't always be plain sailing. But I'm willing to take the bad with the good. I accept the risk.' Think also of the Christian wedding vow, 'for better, for worse, for richer, for poorer, in sickness and in health, to love and to cherish, till death us do part'. Neither partner to the wedding wants there to be poverty or sickness. But part of what it means to commit to the marriage is to be willing to take the rough with the smooth. This is the sort of thing that Rabbi Yehuda bar Simon has in mind when he talks about the act of acceptance.

7. See Rashi's commentary there.

8. Louis Pojman's (1986) account of religious faith is (rightly) eager to exploit this conceptual relationship between faith and hope.

9. There is one appearance of the word in the Hebrew Bible that might cause problems for our analysis - the only one not cited in the body of this article - namely: Isaiah 65:16. There, God is twice described as 'the God of Amen'. But, in context, I would read this use of 'amen' as meta-linguistic. Isaiah is saying that God is the only being to be named in, or to utter, blessings to which we should respond, 'amen', and God is the only 
being in whose name we should swear and thereby use the word 'amen'. Accordingly, this one verse is not, despite appearances to the contrary, a counterexample to Rabbi Yehuda bar Simon's theory.

10. This parenthetical addition is owed to Daniel Howard-Snyder.

11. All translations of Hebrew texts are mine.

12. Although, see note 9 .

13. See for example Howard-Snyder (2013; Idem (2019); Jackson (2019); Kvanvig (2013); Idem (2015); Idem (2018); McKaughan (2013, 2018); McKaughan \& Howard-Snyder (2021).

14. And, indeed I adopt a contextualism about both 'faith' and 'belief such that the required threshold of confidence required in a proposition to be able to count as having faith that it's true, or to count as believing that it's true, will vary from context to context, see Lebens (2021b).

15. That is to say, all of the philosophers cited in note 13, as opposed to, say Scott \& Malcolm (2017), who think that faith includes belief as a central ingredient.

16. As I said in note 5, some people may have been held back from this conclusion simply because the English language doesn't handle propositional faith as easily as it handles propositional belief. English possesses a verb for belief, but not for faith.

17. Thanks to Daniel McKaughan for pointing out the need to clarify this point.

18. This is a feature of emunah (or virtuous faith) to which Aquinas was also sensitive, see his Summa Theologiae (ST II-II. q.4. a.8). Howard-Snyder and McKaughan are right, I think, to criticize St Thomas for thinking that virtuous faith has to be testimonial. As they put it: 'one's faith in relation to one's intimates can be virtuous even if what evidence one has to go on is non-testimonial, as when a mother puts her faith in her son or two friends have faith that their friendship will endure a crisis' (Howard-Snyder \& McKaughan (2021), 214). By contrast, I take Saadya Gaon to be using 'emunah' in a strictly technical sense, without intending to rule out the possibility or the virtue of the sorts of faith that Howard-Snyder and McKaughan appeal to in their response to St Thomas. 19. The Malbim's reading of these verses seems to have been loosely inspired by the Rabbinic Text, Avot D'Rabbi Natan 37:8.

20. Such as Kusch (2002) and Nelson (1993).

21. Sefer Baal Shem Tov, Shemot, 10.

22. Babylonian Talmud, Nedarim 32a.

23. Pesikta Rabbati 21:18.

24. Bereshit Rabba 38:8, 39:1; Zohar 1:86a.

25. As quoted in Berezovsky (1982), 46.

26. Pri Tzadik, Shemot, Parshat Shemot.

27. Poked Ikarim, Ot 4.

28. This direct acquaintance with God might be thought of in terms of Eleonore Stump's (2012) notion of nonpropositional second-personal knowledge.

29. As Dan Howard-Snyder points out, in correspondence: whether or not our knowledge of God will increase the quality of our beliefs about God is perhaps something of a distraction. What Howard-Snyder would rather I emphasize is that 'knowing WHO is not at all like knowing THAT, and so the terms of appraisal of the latter won't apply to the former'. As he quite rightly continues, success conditions for knowing WHO 'aren't going to be grounded in things that are truth-related but rather relationship-related'. Howard-Snyder wants this to be the emphasis, no doubt, because these relationship-related considerations will get us to the heart of what relational faith is all about, such as covenant, faithfulness, and reciprocity. He's absolutely right. But my interest at this point of the article is about epistemology (the study of knowledge), and its norms, more than pistology (the study of faith)! The epistemically interesting question here takes us back to Saadya Gaon. What exactly is the difference that's captured between the person who knows an equation through having calculated it herself, and the person who knows the same equation through having run it through a calculator? Similarly, we might ask, what, of epistemic merit, is added to a person who moves from knowing that a fact obtains, to being acquainted with the fact itself? Nevertheless, I heartily agree that the questions that Howard-Snyder is pushing here are the questions that should be of central interest to the pistologist.

30. My thanks to the editors of this special issue, and to Noam Oren for comments on a previous draft. Thanks also to two anonymous reviewers, one of whom said, simply, 'Amen to that!'

\section{References}

Abrahams I, Haberman J and Manekin C (2007) Belief. In Berenbaum M and Skolnik F (eds), Encyclopaedia Judaica, 2nd edn. New York: Macmillan Reference, pp. 290-294.

Alston W (1996) Belief, acceptance and religious faith. In Jordan J and Howard-Synder D (eds), Faith, Freedom and Rationality. Lanham: Rowman and Littlefield Publishers, pp. 3-28. 
Altmann A (1946) Translator's introduction. In Altmann A (editor and translator) Saadya Gaon: The Book of Doctines and Beliefs. Oxford: East and West Library, pp. 11-22.

Berezovsky SN (1982) נתיבות שלום. Jerusalem: Yeshivat Beit Avraham Slonin.

Buber M (1951) Two Types of Faith. New York: The Macmillan Company.

Gettier E (1963) Is justified true belief knowledge? Analysis 22, 121-123.

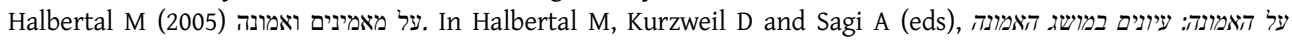
ובתולדותיו במסורת היהודית. Jerusalem: Keter, pp. 11-38.

Heinemann I (1950) אמונהת. In Cassuto MD (ed), אנציקלופדיה מקראית. Jerusalem: Bialik Institute, pp. 426-428.

Howard-Snyder D (2013) Propositional faith: what it is and what it is not. Americal Philosophical Quarterly 50, $357-372$. Howard-Snyder D (2019) Can fictionalists have faith? It all depends. Religious Studies 55, 447-468.

Howard-Snyder D and Mckaughan D (2021) Faith and humility: conflict or concord? In Alfano M, Lynch M and Tanesini A (eds), The Routledge Handbook of the Philosophy of Humility. New York: Routledge, pp. 212-224.

Ibn Yusuf S (1976) The Book of Beliefs and Opinions: Translated from the Arabic and the Hebrew by Samuel Rosenblatt. New Haven: Yale University Press.

Jackson F (1982) Epiphenomenal qualia. The Philosophical Quarterly 32, 127-136.

Jackson E (2019) Belief, credence, and faith. Religious Studies 55, 153-168.

Kohler K (1906) Faith. In Jacobs J (ed), The Jewish Encyclopedia. New York: Funk \& Wagnalls Company, p. 326.

Kusch M (2002) Knowledge by Agreement: The Programme of Communitarian Epistemology. Oxford: Oxford University Press.

Kvanvig J (2013) Affective theism and people of faith. Midwest Studies in Philosophy 37, 109-128.

Kvanvig J (2015) The idea of faith as trust: lessons in noncognitivist approaches to faith. In Bergmann $M$ and Brower J, (eds), Essays on Faith and Reason. Oxford: Oxford University Press.

Kvanvig J (2018) Faith and Humility. Oxford: Oxford University Press.

Lebens S (2021a) Proselytism as epistemic violence: a Jewish approach to the ethics of religious persuasion. The Monist 104, 376-392.

Lebens S (2021b) Will I get a job? Contextualism, belief, and faith. Synthese, 1-22, doi.org/10.1007/s11229-02103045-3.

Leiner MY (1995) מי השלוח. Bnei Brak: The Institute for the Publication of the Works of the Holy Rabbis of IzbicRadzin.

McKaughan DJ (2013) Authentic faith and acknowledged risk: dissolving the problem of faith and reason. Religious Studies 49, 101-124.

McKaughan DJ (2018) Faith through the dark of night: what perseverance amidst doubt can teach us about the nature and value of religious faith. Faith and Philosophy 35, 195-218.

McKaughan D and Howard-Snyder D (2021) Theorizing about faith and faithfulness with Jonathan Kvanvig. Religious Studies, 1-21, doi:10.1017/S0034412521000202.

Nelson L (1993) Who knows? What can they know? And when? Reason Papers 18, 45-56.

Plantinga A (2000) Warranted Christian Belief. Oxford: Oxford University Press.

Pojman L (1986) Faith without belief? Faith and Philosophy 3, 157-176.

Russell B (1914) On the nature of acquaintance, III: analysis of experience. The Monist 24, 435-453.

Scott M and Malcolm F (2017) Faith, belief and fictionalism. Pacific Philosophical Quarterly 98(S1), 257-274.

Stump E (2012) Wandering in Darkness. Oxford: Oxford University Press.

Williamson T (2000) Knowledge and its Limits. Oxford: Oxford University Press.

Cite this article: Lebens S (2021). Amen to daat: on the foundations of Jewish epistemology. Religious Studies 1-14. https://doi.org/10.1017/S0034412521000470 